Article

\title{
Social Exclusion and Labor Market Integration of People with Disabilities. A Case Study for Romania
}

\author{
Felicia Ramona Birau 1,*, Daniela-Emanuela Dănăcică ${ }^{2,3}$ and Cristi Marcel Spulbar ${ }^{3}$ \\ 1 Faculty of Social Science, University of Craiova, 200585 Craiova, Romania \\ 2 Faculty of Economics, Constantin Brâncuși University of Târgu-Jiu, 210135 Târgu-Jiu, Romania; \\ danadde@yahoo.com \\ 3 Faculty of Economics and Business Administration, University of Craiova, 200585 Craiova, Romania; \\ cristi.spulbar@feaa.ucv.ro \\ * Correspondence: ramona.f.birau@gmail.com; Tel.: +40-767-970-777
}

Received: 3 August 2019; Accepted: 9 September 2019; Published: 13 September 2019

\begin{abstract}
This empirical study contributes towards identifying the effect of social exclusion on labor market integration of people with disabilities in Romania. Certain categories of individuals with disabilities have longer unemployment duration than others and this empirical study is focused on identifying which variables have a significant influence on exit to job hazard on Romanian labor market. The significant gap between employees without disabilities and employees with disabilities in the Romanian labor market can be explain based on certain influential factors such as: Lower productivity levels, higher training costs, differentiated work schedules, special demands, higher risk of work injuries and work-related accidents, etc. The findings reveal the lack of statistical significance for the differences between median survival time and hazard rates of disabled individuals, a function of their disability. Moreover, our results show that only an age and unemployment allowance has had a significant effect on unemployment duration and exit to a job hazard of educated individuals with disabilities.
\end{abstract}

Keywords: employees with disabilities; labor market insertion; vulnerable groups; unemployment rate; unemployed; social exclusion

\section{Introduction}

Labor market insertion of individuals with disabilities is a great challenge, especially for developing economies. Demographic ageing of the European Union member states has led to an increasing population, and Romania is no exception. Moreover, the greying of Europe is an irreversible process that is one of the major challenges for world's political leaders considering that demographic factors have a major influence on labor force supply. Population ageing leads inevitably to workforce ageing so appropriate measures to adapt the economy, labor market and working conditions to these changes are needed [1]. As a consequence, the labor force market is contracting so the integration of people with disabilities can be a sustainable alternative. In analyzing social exclusion and labor market integration of people with disabilities we must take into account the fact that Romania is a former communist developing country in Eastern Europe. Inequalities in income, consumption and wealth, high poverty and low living standards are quite common in Romania and vulnerable groups are currently at risk of social exclusion due to insufficient, inadequate or even absent legislative framework. Labor market discrimination is a statistical certainty in Romania, especially for vulnerable groups which also includes people with disabilities.

Romania was under communist rule from 1948 until 1989. Some researchers suggested that since 1991, within a broad based reform package, the government in Romania began to liberalize the labor 
market by allowing wage scales, hiring and promotion criteria to be determined by collective contracts between workers and managers [2].

The Romanian government tried to initiate programs, including external funding, and job creation, but compared to the massive layoffs that occurred following the restructuring of sectors, the number of new jobs created has proved insufficient [3]. Inequality of chance among the citizens of a country such as Romania, inevitably leads to economic and social imbalances based on the inefficient allocation of resources. Governmental authorities in Romania should provide a more sustainable legislative framework for an efficient exploitation of labor market integration opportunities in the case of people with disabilities. On the other hand, the socio-professional integration of people with disabilities is a constant concern of the county agencies for employment in Romania. Moreover, the positive effect of public programs and governmental incentives is significantly diminished by the phenomenon of discrimination faced by people with disabilities. Unfortunately, discrimination is part of the daily routine of most employees with disabilities in Romania even if official statistics do not accurately provide the magnitude of this social phenomenon.

For a better understanding on how to combat workplace discrimination of employees with disabilities in the Romanian labor market, it is essential to have in-depth knowledge of the relevant legislation based on laws, regulations, guidance and other relevant normative acts. However, the regulatory framework is not very rigorous, effective and diversified compared to those of other countries in European Union. Romania signed the Convention on the Rights of Persons with Disabilities and its Optional Protocol (A/RES/61/106) which was adopted on 13 December 2006 at the United Nations Headquarters in New York. This Convention is intended as a human rights instrument and adopts a broad categorization of persons with disabilities and reaffirms that all persons with all types of disabilities must enjoy all human rights and fundamental freedoms. This international legislative framework has made remarkable progress in order to change attitudes and approaches to persons with disabilities. Moreover, this convention established to a new height the movement from viewing persons with disabilities as "objects" of charity, medical treatment and social protection towards viewing persons with disabilities as "subjects" with rights, who are capable of claiming those rights and making decisions for their lives based on their free and informed consent as well as being active members of society [4].

The Constitution of Romania provides the main legal regulatory framework regarding protection of individuals with disabilities because citizens are equal before the law and public authorities, without any discrimination. Moreover, it is also specified that individuals with disabilities shall enjoy special protection and the State of Romania shall provide the accomplishment of a national policy of equal opportunities, and disability prevention and treatment, so that individuals with disabilities can effectively participate in community life, while observing the rights and duties of their parents or legal guardians [5]. According to Law no. 448/2006 amended and completed by the Government Emergency Ordinance no.60/2017 regarding the protection and promotion of the rights of persons with disabilities, starting with 1 September, 2017, public authorities and institutions, legal, public or private persons, who do not employ persons with disabilities will have to pay monthly to the state budget an amount representing the minimum gross monthly guaranteed in payment multiplied by the number of jobs that the company did not employ persons with disabilities [6]. The Romanian Leu, or RON, is the official currency of Romania. At the employer's level there is an impact of raising the minimum gross salary to 1900 Lei on the disability fund contribution paid by the employer because each company having at least 50 employees and that does not hire at least $4 \%$ of the total number of employees individuals with disabilities, is obligated to pay this contribution that is used by the state to protect this social category [7].

As an internal legislative approach, the National Council for Combating Discrimination or NCCD [8] is the Romanian competent and autonomous state authority, under parliamentary control, but it is politically independent which means it operates in the field of discrimination in accordance with the national and international legislation. The National Council for Combating Discrimination 
is a very important national authority in terms of sanctioning discriminatory behavior in order to combat discrimination. The legislative status of NCCD is based on the Government Ordinance no. 137/2000 on preventing and sanctioning all forms of discrimination, which was subsequently amended in 2006. The Government Ordinance no. 137/2000 on preventing and sanctioning all forms of discrimination with subsequent amendments provides the legislative framework in the case of discrimination. The Government Ordinance no. 137/2000 on preventing and sanctioning all forms of discrimination with subsequent amendments implements the Directive no. 2000/43/CE; implementing the principle of equal treatment between persons irrespective of racial or ethnic origin, as well as the Directive no. 2000/78/CE; establishing a general framework for equal treatment in employment and occupation [9]. Practically, this normative act defines discrimination in the Romanian legislation, with direct implications for people with disabilities at risk of social exclusion, as follows: "Any distinction, exclusion, restriction or preference based on race, nationality, ethnicity, language, religion, social status, belief, sex, sexual orientation, age, disability, non-contagious chronic disease, HIV (human immunodeficiency virus) infection, membership of a disadvantaged group and any other criteria which has the purpose or the effect of restriction, elimination of recognition, use or exercise of fundamental human rights and freedoms or of rights recognized by the law in the political, economic, social or cultural field or in any other field of public life. "However, the main contraventional sanctions, according to this law are very low and without major consequences to discourage relapse.

The labor market in Romania is influenced by the economic and social, political system, as well as the environment, that is why the supply and demand of the labor market has had, at many times, different trends [10]. Starting with 1990, Romania was marked by deep socio-economic transformations that have made their critical mark on the evolution of labor nationally and regionally [11]. The labor market in Romania has undergone profound changes resulting from economic reforms in the last nearly two decades, with direct influence on the quality of the human factor [12]. Some researchers argue that Romania has conducted its employment policies rather inconsistently, and therefore, the capacity of the economy to absorb the unemployment is very modest because the economy has destroyed more jobs than it created [13].

The concept of social exclusion was first used by René Lenoir-the French Secretary of State for Social Action in the Government of Prime Minister Jacques Chirac, in late 1974: "Saying that someone is unsuitable, marginal or asocial is simply stating that in the industrialized and urbanized society of the late twentieth century, these persons due to physical or mental, behavior or lack of psychological training, are unable to provide for needs, or require constant care, or represent a danger to others, or are segregated either by their own decision or that of the community". Social exclusion is a multidimensional phenomenon with significant negative impact on various areas such as: Social protection, employment, education, financial services, justice, health, housing, public administration, security, spiritual and religious support, culture, transport, information and communication. It also occurs as a result of shortcomings and failures in the systems and structures of family, community and society [14]. Some researchers defined social exclusion as low material means and inability to participate effectively in economic, social, and cultural life, alienation and distance from the mainstream society [15]. Other researchers suggested that focusing on the "terms and conditions" of social exclusion and inclusion can encompass invisible phenomena, such as mental illness, and bring the concepts closer to underlying social processes [16].

The significant gap between employees with and without disabilities in the Romanian labor market can be explained based on certain influential factors such as: Lower productivity levels, higher training costs, differentiated work schedules, special demands, higher risk of work injuries and work-related accidents, etc. In general, people with disabilities are more exposed to the risk of social exclusion but they are also much less probable to be employed or to receive adequate social assistance. The individual adjustment capacity is impressive in the case of people with disabilities who integrate into the labor market, especially in developing countries such as Romania. In Romania, part-time employees with disabilities are more frequent than full-time employees with disabilities. 
However, the employment rate in the case of people with disabilities is considerably lower than of non-disabled people. The employment gap between people with disabilities and those without is determined by demographic and economic factors, as well as national welfare policies, but with no definitive empirical evidence on their relative strength [17].

\section{Literature Review}

Previous empirical studies suggest that other factors than demographics and injury-related variables, such as differences in the environment or psychological resources that have not been accounted for in this study, may explain a variation in labor market participation (LMP) of persons with disabilities [18]. As an international approach, in Article 27 of the United Nations Convention on the Rights of Persons with Disabilities (CRPD) it is stated that it: "Recognizes the right of persons with disabilities to work, on an equal basis with others; this includes the opportunity to gain a living by work freely chosen or accepted in a labor market and work environment that is open, inclusive and accessible to persons with disabilities" [19].Due to the expected decline in the working-age population, particularly in the case of European countries, people with disabilities are perceived more and more frequently as a valuable resource in the labor force [20]. Previous empirical research studies on labor market integration and equality for people with disabilities in the case of Nordic and Baltic countries, i.e., Denmark, Sweden, Norway, Estonia, Latvia, Lithuania which are all members states of the European Union as well as Romania, suggested that national policies make a difference, that nondiscrimination policies are not enough and that a focused mix of regulatory and redistributive measures is appropriate to be implemented [21]. However, integrating employees with disabilities into the working environment is still a great challenge in Romania.

The ICF-(International Classification of Functioning, Disability and Health) adopts neutral language and does not distinguish between the type and cause of disability-for instance, between "physical" and "mental" health considering that disability arises from the interaction of health conditions with contextual factors-environmental and personal factors [22]. To our knowledge, at the national level, there is a small number of studies focused on the integration into the labor market of individuals with disabilities in Romania. Some researchers encouraged the creation and use of social enterprises for individuals with disabilities by emphasizing the need to use a new concept of "people with disabilities in employment" instead of classical terminology, as well as the importance of social enterprises to support them [23]. Although the term handicap is still used in Romania, certain authors define disability as the main characteristic of a social group with limited activity and restriction of participation, secondary to a significant loss or deviation of the functions or structures of the organism [24].

Some empirical research studies have revealed that the medical model of understanding disability plays a very important role in Romania, in which the impairment remains a solid rationale that justifies the use of patriarchal attitudes by the non-disabled towards individuals with disabilities [25]. In most cases, the medical model and the social model are exposed as dichotomous structures, but disability should be viewed neither as purely medical nor as purely social: Individuals with disabilities can often experience problems arising from their health condition [26]. On the other hand, resilience resources and soft skills confirmed their effectiveness in reducing perceived disability impact and improving perceived employability in the case of youth with disabilities [27].

Some research studies investigated the socio-professional discrimination of individuals with disabilities in Romania and stresses that Romanian employers prefer to pay state contributions to the detriment of employing individuals with disabilities considering that their socio-professional development opportunities are far below those for a person with a normal health condition [28]. The phenomenon of unemployment among people with disabilities is unavoidable and also generates devastating consequences on living standards, wellbeing and quality of life. Labor market insertion of individuals with disabilities implies not only hiring them and receiving a sum of money for their work, but also integrating them into the social life of their community [29]. Currently, Romania is not 
involved in implementing a sustainable demographic strategy in spite of the fact that the labor force is continuously decreasing. Other empirical studies analyzes the duration of unemployment and the destinations of unemployed people registered as unemployed with disabilities in Romania and final results show that age, education and economic status have a significant influence on the probability of (re)employment of individuals with disabilities, during the analyzed period [30].

The employment barriers faced by people with disabilities include the reluctance of employers to hire them and the small number of protected workplaces and a lower pay in comparison with the able-bodied employees in the same job position [31]. The significant implications of educational level on participation in the labor market plays an essential role within policy and research on disability and inclusion considering the fact that educational level has a stronger positive effect for people with disabilities than for non-disabled people [32]. The issue regarding the transition from school to employment has become more important and actual within Romania's economic restructuring [33]. Education is very important in preparing individuals to enter the labor market, by offering them the opportunity to improve and increase their amount of knowledge, skills and abilities [34]. Employees with disabilities can integrate into the workplace accompanied with effective measures focused on empowerment, self-advocacy and social relations over the life span, also considering that disabled peoples' experiences enrich the cultural diversity of the workplace [35].

Previous empirical studies have highlighted that family, training (both prior to and during the integration service), monitoring of the worker with disabilities in the workplace, and work setting were relevant and contributing aspects of the process of work integration [36]. People with disabilities and people without disabilities respond to workplace challenges in different ways. For instance, the global financial crisis of 2008 had a greater impact on people with disabilities than on those without disabilities but in recent years, the unemployment rate among people with disabilities has grown at a faster pace, especially for women and young people [37].

After 1990, the market labor formation and functioning has become one of the priorities of transition and economic reform program in Romania [38]. Empirical studies demonstrate that understanding, supporting and integrating young specialists into the Romanian labor market transcends from microeconomic behavior to the macroeconomic level so it generates a serious national matter [39]. Developed countries unlike most developing countries, including Romania, implement sustainable strategies for labor market integration of people with disabilities. For instance, previous research studies revealed that an Italian employment policy system orientates people with disabilities and reduced work capacity towards the open labor market instead of protected employment and both environmental and socio-welfare factors which should be considered, as they are important in determining the efficiency of each region in providing employment for individuals with disabilities [40]. The main aim of the public employment policy in Romania should focus on a sustainable approach to reducing the number of unemployed people with disabilities based on sustainable and inclusive growth.

On the other hand, in Romania, the "black labor" phenomenon is very widespread. "Black labor" involves a number of negative aspects for employees, such as: Employers pay low wages, mostly under minimum wage, or under what would be fair given the proper level of expertise and experience of the employee, the expertise and labor time performed by workers. These workers are not registered for retirement or disease retirement, or social aid to any illness or death, and have no right to the benefit of an unemployment allowance or health insurance [41].

Possible effective strategies for labor market integration of people with disabilities in the case of a developing country in the EU, such as Bulgaria (Romania's neighbor) involve the following directions stressing on the effectiveness in the talks with the employers on the open labor market; improvement of the relations with the Unions of persons with disabilities, NGOs-Non-governmental organisations and social partners around the country, using the subsidiary principle for solving this social issue, and also finding jobs on the open labor market for people with disabilities by adapting the working place for them [42]. 


\section{Data and Methodology}

For the empirical part of our paper we used micro-data about unemployed people with disabilities registered at the National Agency of Employment Romania (NAE). The dataset has 156 unemployment spells, registered at NAE anytime during 1 January 2014 and 31 October 2017. At the time of research, these were the most recently available data. It was for the first time when we obtained data about the type of disability of unemployed individuals with a poor state of health. To our knowledge, until now there are no papers focused on analyzing the link between the type of disability of an individual, and his/her unemployment duration and exit to a (new) job in Romania. Our aim was to investigate what hides behind the unemployment duration of individuals with disabilities, why some of them have longer unemployment spells than others and if there are significant determinants that influence the exit of a job hazard. The goal was to identify the most vulnerable, among the vulnerable.

The dataset was first carefully analyzed and all the cases with conflictual information (e.g., incongruence between age of the individual and his/her level of education, negative duration of unemployment, etc.) were removed. In addition, we do not have multiple spells for the same individual in our dataset. We would like to underline that we have data only for individuals with disabilities registered as unemployed and who are at least post-high school graduates. At the time of research, only these data were available. For each spell we have information about first and last day in registered unemployment, gender, age, education, county, urban or rural area of living, the status of the individual at the time of registration, if the individual received or not the unemployment allowance, if the individual has previous work experience in the labor market or not, what type of disability he or she has, their profession, their ethnicity, the reason of exit from NAE registration and if the person attended special courses offered by NAE during his/her spell.

Duration of unemployment was the endogenous variable of our study, and it was calculated as the difference between the last and first day in registered unemployment of each individual; the variable is expressed in days. All the explanatory variables of the model are presented in Table 1.

Table 1. Explanatory variables description.

\begin{tabular}{|c|c|}
\hline Explanatory Variables & Description \\
\hline Gender & Dummy variable, 1 -Male, 2-Female \\
\hline Age & $\begin{array}{l}\text { Values in between } 21 \text { and } 60 \text { years, with the following intervals (less than } \\
25),(25-29),(30-39),(40-49),(50-55),(\text { over } 55)\end{array}$ \\
\hline Education & $\begin{array}{l}\text { Dummy variable, with the following categories: 1-ISCED4, post-high } \\
\text { school, 2-ISCED6, university education and 3-ISCED7 master level. }\end{array}$ \\
\hline Region & $\begin{array}{l}\text { Dummy variable, with the following categories: 1-North-East, } \\
\text { 2-South-East, 3-South-Muntenia, 4-South-West Oltenia, 5-West, } \\
\text { 6-North-West, 7-Centre, 8-Bucharest-Ilfov }\end{array}$ \\
\hline Area of living & Dummy variable, 0 -rural area, 1 - urban area \\
\hline Previous work experience & $\begin{array}{c}\text { Dummy variable, } 0 \text { —for first time job seekers, } 1 \text {-for individuals with a } \\
\text { previous work experience }\end{array}$ \\
\hline Unemployment allowance status & $\begin{array}{l}\text { Dummy variable, } 0 \text { - for unemployed with disabilities without allowance, } \\
1 \text {-for unemployed with disabilities who receive unemployment allowance }\end{array}$ \\
\hline Type of disability & $\begin{array}{l}\text { Dummy variable, with the following categories: 1-Physical/Locomotive } \\
\text { disability, 2-Somatic disability, 3-Visual disability, 4-psychic disability, } \\
\text { 5-hearing disability, 6-mental disability, 7-deafblind, 8-HIV (human } \\
\text { immunodeficiency virus)-AIDS (the late stage of HIV infection), 9-rare } \\
\text { disease, 10-other disability }\end{array}$ \\
\hline Ethnicity & Dummy variable, 1 -Romanian, 2-other (Rrom and Hungarian) \\
\hline Entry year in unemployment & $1-2014,2-2015,3-2016,4-2017$ \\
\hline
\end{tabular}

A very important information that we received from NAE was the reason of exit from unemployment for each individual. When the spell ends, the unemployed was deactivated from 
registration. Out of all 156 unemployment spells, 82 (52.56\%) had not mentioned the reason for the end. For the rest of the 72 spells, we have 11 different reasons of deactivation in our dataset. We grouped these deactivation reasons into five categories: 1 -Exit due to a job, 2-deactivation due to expiry of the legal period for receiving unemployment allowance, 3-deactivation due to individual own fault, 4-exit due to non-participation (inactivity) and 5-censored (all the spells without a specified reason of deactivation or an unclear reason of deactivation).

\section{Dataset Preliminary Statistics}

Out of all 156 spells, 33.3\% ended due to (re)employment, 3.2\% were deactivated due to expiry of the legal period for receiving unemployment allowance, $7.7 \%$ were deactivated due to individual fault, $2.6 \%$ were deactivated because individuals exit in non-participation and $53.2 \%$ do not have a reason for deactivation. The distribution of unemployment spells of individuals with disabilities is presented in Figure 1. Unemployment duration has a range of 729 days and a mean duration of 219.79 days. Central tendency statistics are presented in Table 2.

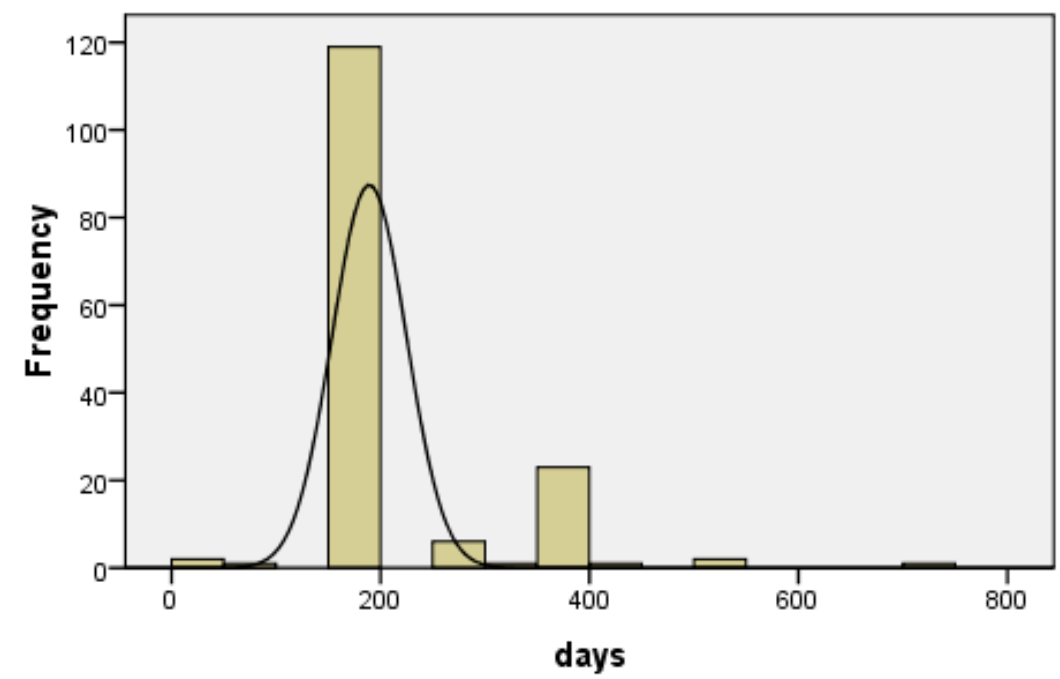

Mean $=219.79$ Std. Dev. $=91.94$

Figure 1. Distribution of unemployment spells (days). Source: Authors' processing in SPSS-(Statistical Package for the Social Sciences) based on data provided by National Agency of Employment Romania (NAE).

Table 2. Central tendency statistics for unemployment spells.

\begin{tabular}{ccccc}
\hline \multirow{2}{*}{ Central Tendency Indicators } & Mean & $95 \%$ Confidence interval for mean & Median & Mode \\
& 219.79 & $(205.25,234.34)$ & 183.00 & 184 \\
\hline \multirow{2}{*}{ Variance } & Std. Deviation & Range & \\
& 91.940 & Kurtosis & \\
\hline \multirow{2}{*}{ Skewness and Kurtosis } & Skewness & 7.083 & \\
& 2.137 & & \\
\hline
\end{tabular}

Source: Authors' processing in SPSS based on data provided by NAE.

Out of all 156 duration of individuals with disabilities, 60 belonged to individuals with physical/locomotive disabilities, 19 to individuals with somatic disabilities, 15 to individuals with hearing disabilities, 14 to individuals with visual disabilities, 13 to individuals with psychic disabilities, five to individuals with mental disabilities, four to individuals with deaf or blind disabilities, two individuals had rare diseases and 23 individuals had other disabilities. Seventy-five unemployment durations belonged to women and 81 durations belonged to men. The mean unemployment duration for women was 219.63 days and for men it was 219.95 days. The distribution of unemployment spells by age was as follows: 28 spells belonged to individuals aged less than 25 years, 46 spells belonged to individuals with disabilities aged in between 25-29 years, 47 spells for the 30-39 age group, 25 spells 
for the 40-49 group, six spells for the 50-55 group, and four spells belonged to individuals aged over 55 years. As we can notice, $77.5 \%$ of our subjects were individuals with disabilities aged less than 40 years. By education we have the following distribution of unemployment spells: Thirty-four belonged to ISCED-International Standard Classification of Education 4 individuals with disabilities. Seventy spells belonged to individuals who graduated long-term university education, and 52 spells were ISCED6 individuals. A total of $21.8 \%$ of the spells belonged to individuals from a rural area, and $78.2 \%$ to individuals from an urban area. One hundred and fifty-three individuals with disabilities were Romanians, one was Hungarian and two were from the Roma population. Sixty-two subjects had previous work experience and 94 were first-time job seekers with disabilities. As for the entry year in unemployment, we obtained the following distribution: Six individuals with disabilities registered in unemployment in 2014, 17 in 2015, 46 in 2016 and 87 in 2017.

\section{Empirical Results and Discussion}

The purpose of our research was to analyze why some individuals with disabilities have longer unemployment duration than others and which variables have a significant influence on exit to job hazard. Moreover, we want to analyze if the type of disability has had an effect on unemployment duration and exit to a job hazard, and which group is the most vulnerable on the labor market. We used the Cox proportional hazard model in a competing risks approach and the non-parametric estimation of the survival function to estimate the effect of the above presented explanatory variables on unemployment duration, exit states and exit to a job hazard. We have the following regression equation:

$$
\lambda(t)=\lambda_{0}(t) \exp \left\{\begin{array}{l}
\text { gender } \cdot \beta_{1}+\text { age } \cdot \beta_{2}+\text { education } \cdot \beta_{3}+\text { disability } \cdot \beta_{4}+\text { area } \cdot \beta_{4}+\text { region } \cdot \beta_{5}+ \\
\text { UI } \cdot \beta_{6}+\text { experience } \cdot \beta_{7}+\text { ethnicity } \cdot \beta_{8}+\text { year } \cdot \beta_{9}
\end{array}\right\}
$$

where $\beta_{1}, \ldots \beta_{9}$ are the regression coefficients, $\lambda_{0}$ is the baseline hazard and $\lambda(t)$ is the hazard rate, measuring the instantaneous "death" rate of an individual at the time $t$, conditional on survival of the individuals until the time $t$. In our study, $\lambda(t)$ gives the hazard that an individual who is still unemployed in day $t$ to exit to a job, or exit due to expiry of the legal period for getting UI-Unemployment Insurance, or exit due to individual own fault, or exit in non-participation in the very next day.

In our dataset we had 156 registered unemployment spells of individuals with disabilities who graduated with an ISCED4, ISCED6 or ISCED7 level of education. Only 33.33\% of spells were deactivated due to (re)employment, $3.2 \%$ were deactivated due to expiry of the legal period for receiving unemployment allowance, $7.7 \%$ were deactivated due to individual fault, $2.6 \%$ were deactivated because individuals exit in non-participation and $53.2 \%$ do not have a reason for deactivation. In Table 3 we have presented the distribution of the total unemployment spells and the distribution of spells deactivated due to (re)employment, by type of disability. We calculated a rate of employability as a percent of spells deactivate due to (re)employment and total spells, for each type of disability and mean unemployment duration until each individual with a disability finds a job.

Table 3. Distribution of total spells and spells ended in employment, by type of disability.

\begin{tabular}{ccccc}
\hline \multicolumn{5}{c}{ Unemployment Spells } \\
\hline Type of Disability & Registered Spells & $\begin{array}{c}\text { Spells Deactivated due } \\
\text { to (Re)employment }\end{array}$ & $\begin{array}{c}\text { Rate of } \\
\text { Employability (\%) }\end{array}$ & $\begin{array}{c}\text { Mean Unemployment Duration } \\
\text { until (Re)employment Occurs } \\
\text { (days) }\end{array}$ \\
\hline $\begin{array}{c}\text { Physical/Locomotive } \\
\text { disability }\end{array}$ & 60 & 23 & 38.33 & 190.04 \\
\hline Somatic disability & 19 & 6 & 31.58 & 212.83 \\
\hline Visual disability & 14 & 7 & 50 & 182.71 \\
\hline Psychic disability & 13 & 2 & 15.38 & 184 \\
\hline Hearing disability & 15 & 5 & 33.33 & 182.40 \\
\hline
\end{tabular}


Table 3. Cont.

\begin{tabular}{ccccc}
\hline \multicolumn{5}{c}{ Unemployment Spells } \\
\hline Type of Disability & Registered Spells & $\begin{array}{c}\text { Spells Deactivated due } \\
\text { to (Re)employment }\end{array}$ & $\begin{array}{c}\text { Rate of } \\
\text { Employability (\%) }\end{array}$ & $\begin{array}{c}\text { Mean Unemployment Duration } \\
\text { until (Re)employment Occurs } \\
\text { (days) }\end{array}$ \\
\hline Mental disability & 5 & 0 & 0 & 184 \\
\hline Deafblind & 4 & 1 & 25 & 184 \\
\hline HIV-AIDS & 1 & 0 & 50 & 260.57 \\
\hline Rare disease & 2 & 1 & 30.43 & 199.98 \\
\hline Other disability & 23 & 7 & 33.33 & \\
\hline Total & 156 & 52 & Source: Authors' process using SPSS.
\end{tabular}

From these descriptive statistics we, noticed differences between the unemployed with disabilities, due to their type of disability. It seems that individuals with a psychic or a mental disability are in the worse position in the labor market. Individuals with a visual disability have the highest employability rate and the shortest mean unemployment duration until (re)employment occurs. The next step was to apply the Cox proportional hazard model in a competing risks approach to the data. The reference category is first for each explanatory variable. The enter method was selected. We used SPSS (Statistical Package for the Social Sciences) 17.0 for data processing. All the explanatory variables were simultaneously introduced in the model.

The results are presented in Tables A1-A3 in Appendix A. As we can notice from Table A1 in Appendix A, we even have differences between hazards of the unemployed with disabilities, a function on their disability type, however, we lack statistical significance for these differences. We obtained the same lack of statistical significance when we estimated median survival time for each group, using the Kaplan-Meier estimator. Therefore, we cannot draw a conclusion about the effect of disability type on unemployment duration and exit to a job hazard. Unfortunately, the same situation is registered for the other explanatory variables, except the difference between exit to a job hazard between the unemployed with disabilities aged in between 25 and 29 years and the unemployed with disabilities aged less than 25 years, and the difference of exit to a job hazard between individuals with disabilities who received UI and those who do not. At any point in our study, an unemployed person with disabilities aged in between 25 and 29 years had an almost three times higher exit to a job chance than one aged less than 25 years. Further, in the case of individuals with disabilities too, receiving unemployment benefits led to a longer unemployment duration and a lower exit to job hazard. Mean survival time until exit from a job is 380.593 days for individuals with disabilities had not received an unemployment allowance, compared with 405.346 for individuals with disabilities who received an unemployment allowance (calculated with the Kaplan-Meier estimator). Furthermore, the result is highly significant. When the expected event is in deactivation due to the expiry of the legal period for receiving an unemployment allowance, none of the explanatory variables have a statistically significant effect on survival. Unemployed people with disabilities who receive the unemployment allowance are more careful not to get out from unemployment due to their own fault than who do not receive the unemployment allowance (Table A3, Appendix A). We have only four spells deactivated due to the exit of individuals in non-participation (inactivity) on the labor market. Since none of the explanatory variables have had a significant effect on survival when the event is exit due to inactivity, in addition to the lack of space, we decided to not present another table with regression coefficients for this particular event.

\section{Conclusions}

The aim of this research was to investigate social exclusion and labor market integration of individuals with disabilities in Romania. Labor market insertion of individuals with disabilities is a great challenge for any society, and especially for developing countries. Individuals with disabilities 
are a vulnerable population. The main problem that individuals with disabilities from Romania have to face it is not the disability itself, but poor infrastructure, the challenges of transportation to and from the workplace, and social stigma and discrimination. These are strong reasons why many individuals with disabilities quit searching for a job or have difficulties keeping their current job. Some Romanian employers avoid hiring people with disabilities due to the necessity to adapt their working conditions to the needs of this particular group. Inequalities in income, consumption and wealth, high poverty, social stigma and low living standards are quite common in Romania and vulnerable groups are at risk of social exclusion due to insufficient, inadequate or even absent current legislative framework.

The Romanian legislation is constantly changing and adapting because the Romanian legislator has amended the general law regarding individual and collective labor relations, reforming the legal concepts and institutions in the field in order to establish more flexible legal relations between employers and employees [43]. Romania has already aligned its legislation to the EU policies on combating discrimination in the case of persons with disabilities, however, the concrete results are difficult to commensurate. Moreover, the ICF adopts neutral language to eliminate any form of discrimination regarding persons with disabilities [44]. All these were a strong motivation to authors to focus on such an important and impacting subject.

The empirical analysis is based on a dataset provided by NAE Romania, with information about all the individuals with disabilities who are at least post-high school graduates registered as unemployed anytime between 1 January 2014 and 31 October 2017. As a methodological approach we used the Cox proportional hazard model in a competing risks framework and the non-parametric estimation of the survival function to estimate the effect of a set of personal characteristics of individuals with disabilities on unemployment duration and exit to job hazard. However, the results showed a lack of statistical significance for the differences between median survival time and the hazard rates of individuals with disabilities, as a function of their disability. Thus, we cannot draw a conclusion about the impact of different categories of disability on unemployment duration and exit to job hazard for this dataset. However, the results show that the age and unemployment allowance had a significant effect on unemployment duration and exit to a job hazard of individuals with disabilities. However, we must take into account that analyzed individuals are graduates of at least post-high-school (some of them are university or master level graduates), and the education variable may cause differences generated by the type of disability of individuals to be erased. As we know from previous studies, the presence of a high education leads to the attenuation of differences generated by different characteristics on the duration of unemployment and exit to job hazard. As for future research, we will try to obtain data about all educational groups of individuals with disabilities registered in unemployment for a particular period of time and analyze the impact of types of disability on their outcome. At this time, we had data only for individuals with disabilities who are at least post-high school graduates. Moreover, as a final remark, we would like to underline that the measures implemented by the Romanian Government until now are still insufficient to solve the problem of social exclusion and labor market integration for this vulnerable population. There are many companies in Romania that do not have at least one individual with a disability as a member of their staff. Implementing a sustainable strategy to combat social exclusion and to stimulate labor market integration of people with disabilities should become one of the highest priorities of governmental authorities in Romania. However, people with disabilities do not always express those individual capabilities that allow them to cope with workplace requirements. Thus, social exclusion and labor market integration of individuals with disabilities remains an insufficiently investigated topic that requires special attention from policy makers, as well as from researchers and civil society.

Author Contributions: F.R.B., D.-E.D. and C.M.S. contributed equally to this research work. All authors discussed the results and contributed to the final manuscript. All authors read and approved the final manuscript.

Funding: This research received no external funding.

Acknowledgments: This work was supported by the grant POCU 380/6/13/123990, co-financed by the European Social Fund within the Sectorial Operational Program Human Capital 2014-2020. 
Conflicts of Interest: The authors declare no conflicts of interest.

\section{Appendix A}

Table A1. Cox proportional hazard model results, event (re)employment.

\begin{tabular}{|c|c|c|c|c|c|c|c|c|}
\hline \multirow{2}{*}{ Explanatory Variables } & \multirow{2}{*}{ B } & \multirow{2}{*}{ SE } & \multirow{2}{*}{ Wald } & \multirow{2}{*}{ df } & \multirow{2}{*}{ Sig. } & \multirow{2}{*}{$\operatorname{Exp}(B)$} & \multicolumn{2}{|c|}{$95.0 \%$ CI for $\operatorname{Exp}(B)$} \\
\hline & & & & & & & Lower & Upper \\
\hline Men & \multicolumn{8}{|c|}{ Reference category } \\
\hline Women & 0.202 & 0.332 & 0.371 & 1 & 0.542 & 1.224 & 0.638 & 2.348 \\
\hline Less than 25 years & \multicolumn{8}{|c|}{ Reference category } \\
\hline $25-29$ years & 0.976 & 0.490 & 3.973 & 1 & 0.046 & 2.655 & 1.016 & 6.935 \\
\hline 30-39 years & 0.844 & 0.546 & 2.390 & 1 & 0.122 & 2.325 & 0.798 & 6.778 \\
\hline $40-49$ years & 0.713 & 0.714 & 0.996 & 1 & 0.318 & 2.040 & 0.503 & 8.271 \\
\hline $50-55$ years & -0.186 & 1.335 & 0.019 & 1 & 0.889 & 0.830 & 0.061 & 11.362 \\
\hline Over 55 years & 1.362 & 1.320 & 1.065 & 1 & 0.302 & 3.903 & 0.294 & 51.872 \\
\hline ISCED 4-posthighschool & \multicolumn{8}{|c|}{ Reference category } \\
\hline University education & 0.121 & 0.436 & 0.077 & 1 & 0.781 & 1.129 & 0.480 & 2.652 \\
\hline Master level & 0.014 & 0.508 & 0.001 & 1 & 0.978 & 1.014 & 0.374 & 2.746 \\
\hline Physical/Locomotive disability & \multicolumn{8}{|c|}{ Reference category } \\
\hline Somatic disability & 0.321 & 0.516 & 0.387 & 1 & 0.534 & 1.379 & 0.501 & 3.793 \\
\hline Visual disability & 0.340 & 0.533 & 0.408 & 1 & 0.523 & 1.405 & 0.495 & 3.990 \\
\hline Psychic disability & -1.234 & 0.854 & 2.089 & 1 & 0.148 & 0.291 & 0.055 & 1.552 \\
\hline Hearing disability & 0.517 & 0.536 & 0.932 & 1 & 0.334 & 1.677 & 0.587 & 4.791 \\
\hline Mental disability & -9.532 & 83.903 & 0.013 & 1 & 0.910 & 0.000 & 0.000 & $1.899 \mathrm{E} 67$ \\
\hline Deafblind & 0.276 & 1.252 & 0.049 & 1 & 0.826 & 1.318 & 0.113 & 15.342 \\
\hline HIV-AIDS & -10.060 & 256.409 & 0.002 & 1 & 0.969 & 0.000 & 0.000 & $7.711 \mathrm{E} 213$ \\
\hline Rare disease & 0.571 & 1.220 & 0.219 & 1 & 0.640 & 1.770 & 0.162 & 19.342 \\
\hline Other disability & -0.263 & 0.578 & 0.206 & 1 & 0.650 & 0.769 & 0.248 & 2.388 \\
\hline Rural & \multicolumn{8}{|c|}{ Reference category } \\
\hline Urban & 0.252 & 0.454 & 0.308 & 1 & 0.579 & 1.287 & 0.528 & 3.134 \\
\hline North-East & \multicolumn{8}{|c|}{ Reference category } \\
\hline South-East & -0.015 & 0.705 & 0.000 & 1 & 0.983 & 0.985 & 0.247 & 3.924 \\
\hline South-Muntenia & 0.114 & 0.510 & 0.050 & 1 & 0.823 & 1.121 & 0.413 & 3.044 \\
\hline South-West Oltenia & -8.631 & 54.806 & 0.025 & 1 & 0.875 & 0.000 & 0.000 & $7.995 \mathrm{E} 42$ \\
\hline West & 0.125 & 0.603 & 0.043 & 1 & 0.836 & 1.133 & 0.347 & 3.695 \\
\hline North-West & 0.258 & 0.495 & 0.271 & 1 & 0.603 & 1.294 & 0.490 & 3.417 \\
\hline Centre & -0.005 & 0.589 & 0.000 & 1 & 0.993 & 0.995 & 0.314 & 3.154 \\
\hline Bucharest-Ilfov & -0.973 & 0.845 & 1.325 & 1 & 0.250 & 0.378 & 0.072 & 1.981 \\
\hline Without UI & \multicolumn{8}{|c|}{ Reference category } \\
\hline With UI & -2.125 & 0.793 & 7.177 & 1 & 0.007 & 0.119 & 0.025 & 0.565 \\
\hline Without experience & \multicolumn{8}{|c|}{ Reference category } \\
\hline With experience & -0.433 & 0.439 & 0.972 & 1 & 0.324 & 0.648 & 0.274 & 1.534 \\
\hline Romanian & \multicolumn{8}{|c|}{ Reference category } \\
\hline Other & 0.977 & 1.204 & 0.659 & 1 & 0.417 & 2.658 & 0.251 & 28.145 \\
\hline 2014 & \multicolumn{8}{|c|}{ Reference category } \\
\hline 2015 & 8.636 & 73.983 & 0.014 & 1 & 0.907 & 5631.267 & 0.000 & 5.313E66 \\
\hline 2016 & 7.979 & 73.980 & 0.012 & 1 & 0.914 & 2917.932 & 0.000 & $2.734 \mathrm{E} 66$ \\
\hline 2017 & 7.803 & 73.980 & 0.011 & 1 & 0.916 & 2446.809 & 0.000 & $2.291 \mathrm{E} 66$ \\
\hline
\end{tabular}

Source: Authors' processing in SPSS based on data provided by NAE. 
Table A2. Cox proportional hazard model results, event expiry of the legal period for UI.

\begin{tabular}{|c|c|c|c|c|c|c|c|c|}
\hline \multirow{2}{*}{ Explanatory Variables } & \multirow{2}{*}{ B } & \multirow{2}{*}{$\mathrm{SE}$} & \multirow{2}{*}{ Wald } & \multirow{2}{*}{ df } & \multirow{2}{*}{ Sig. } & \multirow{2}{*}{$\operatorname{Exp}(B)$} & \multicolumn{2}{|c|}{ 95.0\% CI for $\operatorname{Exp}(B)$} \\
\hline & & & & & & & Lower & Upper \\
\hline Men & \multicolumn{8}{|c|}{ Reference category } \\
\hline Women & -1.380 & 3.487 & 0.157 & 1 & 0.692 & 0.251 & 0.000 & 233.563 \\
\hline Less than 25 years & \multicolumn{8}{|c|}{ Reference category } \\
\hline 25-29 years & 1.444 & 8.370 & 0.030 & 1 & $0.863^{\circ}$ & 4.240 & 0.000 & $5.650 \mathrm{E} 7$ \\
\hline $30-39$ years & 1.142 & 10.946 & 0.011 & 1 & 0.917 & 3.132 & 0.000 & $6.496 \mathrm{E} 9$ \\
\hline $40-49$ years & 2.815 & 10.371 & 0.074 & 1 & 0.786 & 16.690 & 0.000 & 1.123E10 \\
\hline $50-55$ years & -1.392 & 11.286 & 0.015 & 1 & 0.902 & 0.248 & 0.000 & $1.005 \mathrm{E} 9$ \\
\hline Over 55 years & 2.417 & 14.524 & 0.028 & 1 & 0.868 & 11.210 & 0.000 & $2.584 \mathrm{E} 13$ \\
\hline ISCED 4-posthighschool & \multicolumn{8}{|c|}{ Reference category } \\
\hline University education & -0.782 & 8.205 & 0.009 & 1 & $0.924^{\circ}$ & 0.458 & 0.000 & $4,408,541.977$ \\
\hline Master level & -1.035 & 8.034 & 0.017 & 1 & 0.897 & 0.355 & 0.000 & $2,449,257.201$ \\
\hline \multicolumn{9}{|l|}{ Physical/Locomotive disability } \\
\hline Somatic disability & -0.951 & 5.271 & 0.033 & 1 & 0.857 & 0.386 & 0.000 & 11856.050 \\
\hline Visual disability & -1.425 & 9.066 & 0.025 & 1 & 0.875 & 0.240 & 0.000 & $1.254 \mathrm{E} 7$ \\
\hline Psychic disability & -4.634 & 9.811 & 0.223 & 1 & 0.637 & 0.010 & 0.000 & $2,179,747.851$ \\
\hline Hearing disability & -3.198 & 6.514 & 0.241 & 1 & 0.623 & 0.041 & 0.000 & $14,312.213$ \\
\hline Mental disability & -4.351 & 34.035 & 0.016 & 1 & 0.898 & 0.013 & 0.000 & $1.204 \mathrm{E} 27$ \\
\hline Deafblind & 0.681 & 52.036 & 0.000 & 1 & 0.990 & 1.975 & 0.000 & 3.879E44 \\
\hline HIV-AIDS & -5.413 & 194.114 & 0.001 & 1 & 0.978 & 0.004 & 0.000 & 7.573E162 \\
\hline Rare disease & -2.630 & 18.094 & 0.021 & 1 & 0.884 & 0.072 & 0.000 & $1.816 \mathrm{E} 14$ \\
\hline Other disability & -2.906 & 7.059 & 0.169 & 1 & 0.681 & 0.055 & 0.000 & $55,806.966$ \\
\hline Rural & \multicolumn{8}{|c|}{ Reference category } \\
\hline Urban & 1.118 & 9.548 & 0.014 & 1 & $0.907^{\circ}$ & 3.059 & 0.000 & $4.102 \mathrm{E} 8$ \\
\hline North-East & \multicolumn{8}{|c|}{ Reference category } \\
\hline South-East & 0.973 & 15.738 & 0.004 & 1 & $0.951^{\circ}$ & 2.645 & 0.000 & 6.584E13 \\
\hline South-Muntenia & 0.833 & 13.653 & 0.004 & 1 & 0.951 & 2.301 & 0.000 & 9.633E11 \\
\hline South-West Oltenia & 7.881 & 12.657 & 0.388 & 1 & 0.533 & 2647.091 & 0.000 & $1.571 \mathrm{E} 14$ \\
\hline West & -1.308 & 13.040 & 0.010 & 1 & 0.920 & 0.270 & 0.000 & 3.402E10 \\
\hline North-West & -0.036 & 12.131 & 0.000 & 1 & 0.998 & 0.965 & 0.000 & 2.044E10 \\
\hline Centre & 3.536 & 11.276 & 0.098 & 1 & 0.754 & 34.326 & 0.000 & $1.362 \mathrm{E} 11$ \\
\hline Bucharest-Ilfov & 0.294 & 11.254 & 0.001 & 1 & 0.979 & 1.342 & 0.000 & $5.098 \mathrm{E} 9$ \\
\hline Without experience & \multicolumn{8}{|c|}{ Reference category } \\
\hline With experience & 1.141 & 6.651 & 0.029 & 1 & 0.864 & 3.131 & 0.000 & $1,436,384.172$ \\
\hline Romanian & \multicolumn{8}{|c|}{ Reference category } \\
\hline Other & 0.672 & 32.737 & 0.000 & 1 & 0.984 & 1.959 & 0.000 & $1.437 \mathrm{E} 28$ \\
\hline 2014 & \multicolumn{8}{|c|}{ Reference category } \\
\hline 2015 & 0.866 & 39.590 & 0.000 & 1 & 0.983 & 2.378 & 0.000 & 1.190E34 \\
\hline 2016 & 3.531 & 39.295 & 0.008 & 1 & 0.928 & 34.152 & 0.000 & $9.585 \mathrm{E} 34$ \\
\hline 2017 & 0.285 & 39.343 & 0.000 & 1 & 0.994 & 1.329 & 0.000 & $4.096 \mathrm{E} 33$ \\
\hline
\end{tabular}

Source: Authors' processing in SPSS based on data provided by NAE.

Table A3. Cox proportional hazard model results, deactivation due to individual fault.

\begin{tabular}{|c|c|c|c|c|c|c|c|c|}
\hline \multirow{2}{*}{ Explanatory Variables } & \multirow{2}{*}{ B } & \multirow{2}{*}{ SE } & \multirow{2}{*}{ Wald } & \multirow{2}{*}{ df } & \multirow{2}{*}{ Sig. } & \multirow{2}{*}{$\operatorname{Exp}(B)$} & \multicolumn{2}{|c|}{$95.0 \%$ CI for $\operatorname{Exp}(B)$} \\
\hline & & & & & & & Lower & Upper \\
\hline Men & \multicolumn{8}{|c|}{ Reference category } \\
\hline Women & 69.386 & 41.077 & 2.853 & 1 & 0.091 & $1.361 \mathrm{E} 30$ & 0.000 & $1.256 \mathrm{E} 65$ \\
\hline \multicolumn{9}{|l|}{ Less than 25 years } \\
\hline $25-29$ years & -63.026 & 39.038 & 2.607 & 1 & 0.106 & 0.000 & 0.000 & $719,975.506$ \\
\hline 30-39 years & -82.259 & 48.891 & 2.831 & 1 & 0.092 & 0.000 & 0.000 & $779,235.711$ \\
\hline $40-49$ years & -145.574 & 86.886 & 2.807 & 1 & 0.094 & 0.000 & 0.000 & $5.440 \mathrm{E} 10$ \\
\hline $50-55$ years & -142.797 & 169.214 & 0.712 & 1 & 0.399 & 0.000 & 0.000 & $1.045 \mathrm{E} 82$ \\
\hline Over 55 years & -90.930 & 373.070 & 0.059 & 1 & 0.807 & 0.000 & 0.000 & $1.168 \mathrm{E} 278$ \\
\hline ISCED 4-posthighschool & \multicolumn{8}{|c|}{ Reference category } \\
\hline University education & 121.444 & 80.015 & 2.304 & 1 & 0.129 & 5.527E52 & 0.000 & 7.104E120 \\
\hline Master level & 89.347 & 63.951 & 1.952 & 1 & 0.162 & $6.352 \mathrm{E} 38$ & 0.000 & $1.730 \mathrm{E} 93$ \\
\hline
\end{tabular}


Table A3. Cont.

\begin{tabular}{|c|c|c|c|c|c|c|c|c|}
\hline \multirow{2}{*}{ Explanatory Variables } & \multirow{2}{*}{ B } & \multirow{2}{*}{ SE } & \multirow{2}{*}{ Wald } & \multirow{2}{*}{ df } & \multirow{2}{*}{ Sig. } & \multirow{2}{*}{$\operatorname{Exp}(B)$} & \multicolumn{2}{|c|}{$95.0 \%$ CI for $\operatorname{Exp}(B)$} \\
\hline & & & & & & & Lower & Upper \\
\hline Physical/Locomotive disability & \multicolumn{8}{|c|}{ Reference category } \\
\hline Somatic disability & -7.386 & 7.461 & 0.980 & 1 & 0.322 & 0.001 & 0.000 & 1390.426 \\
\hline Visual disability & -87.325 & 145.087 & 0.362 & 1 & 0.547 & 0.000 & 0.000 & $3.744 \mathrm{E} 85$ \\
\hline Psychic disability & 102.538 & 60.207 & 2.900 & 1 & 0.089 & $3.401 \mathrm{E} 44$ & 0.000 & $6.028 \mathrm{E} 95$ \\
\hline Hearing disability & 134.739 & 80.665 & 2.790 & 1 & 0.095 & $3.284 \mathrm{E} 58$ & 0.000 & $1.509 \mathrm{E} 127$ \\
\hline Mental disability & 163.764 & 698.428 & 0.055 & 1 & 0.815 & $1.324 \mathrm{E} 71$ & 0.000 & \\
\hline Deafblind & -62.339 & 393.858 & 0.025 & 1 & 0.874 & 0.000 & 0.000 & $1.509 \mathrm{E} 308$ \\
\hline HIV-AIDS & 295.724 & 2333.010 & 0.016 & 1 & 0.899 & $2.700 \mathrm{E} 128$ & 0.000 & \\
\hline Rare disease & 135.729 & 211.208 & 0.413 & 1 & 0.520 & $8.838 \mathrm{E} 58$ & 0.000 & 5.337E238 \\
\hline Other disability & 102.645 & 61.140 & 2.819 & 1 & 0.093 & $3.786 \mathrm{E} 44$ & 0.000 & 4.174E96 \\
\hline Rural & \multicolumn{8}{|c|}{ Reference category } \\
\hline Urban & -103.350 & 61.079 & 2.863 & 1 & 0.091 & 0.000 & 0.000 & $1.277 \mathrm{E} 7$ \\
\hline North-East & \multicolumn{8}{|c|}{ Reference category } \\
\hline South-East & -173.959 & 293.079 & 0.352 & 1 & 0.553 & 0.000 & 0.000 & 8.311E173 \\
\hline South-Muntenia & -48.840 & 29.833 & 2.680 & 1 & 0.102 & 0.000 & 0.000 & $15,239.188$ \\
\hline South-West Oltenia & -63.132 & 195.748 & 0.695 & 1 & 0.405 & 0.000 & 0.000 & $5.942 \mathrm{E} 95$ \\
\hline West & -1.114 & 6.667 & 0.028 & 1 & 0.867 & 0.328 & 0.000 & $155,423.063$ \\
\hline North-West & 16.624 & 11.154 & 2.221 & 1 & 0.136 & $1.658 \mathrm{E} 7$ & 0.005 & $5.175 \mathrm{E} 16$ \\
\hline Centre & -99.290 & 60.173 & 2.723 & 1 & 0.099 & 0.000 & 0.000 & $1.254 \mathrm{E} 8$ \\
\hline Bucharest-Ilfov & -15.078 & 12.229 & 1.520 & 1 & 0.218 & 0.000 & 0.000 & 7269.491 \\
\hline Without UI & \multicolumn{8}{|c|}{ Reference category } \\
\hline With UI & -267.230 & 156.126 & 2.930 & 1 & 0.087 & 0.000 & 0.000 & $6.886 \mathrm{E} 16$ \\
\hline Without experience & \multicolumn{8}{|c|}{ Reference category } \\
\hline With experience & -46.362 & 28.466 & 2.652 & 1 & 0.103 & 0.000 & 0.000 & $12,472.403$ \\
\hline Romanian & \multicolumn{8}{|c|}{ Reference category } \\
\hline Other & -14.751 & 618.211 & 0.001 & 1 & 0.981 & 0.000 & 0.000 & \\
\hline 2014 & \multicolumn{8}{|c|}{ Reference category } \\
\hline 2015 & 16.785 & 23.893 & 0.493 & 1 & 0.482 & 1.947E7 & 0.000 & $4.238 \mathrm{E} 27$ \\
\hline 2016 & -228.855 & 136.814 & 2.798 & 1 & 0.094 & 0.000 & 0.000 & $1.164 \mathrm{E} 17$ \\
\hline 2017 & -145.146 & 90.239 & 2.587 & 1 & 0.108 & 0.000 & 0.000 & $5.963 \mathrm{E} 13$ \\
\hline
\end{tabular}

Source: Authors' processing in SPSS based on data provided by NAE.

\section{References and Notes}

1. Pisica, S.; Vasile, V.; Dobre, A.M. Labour market for youth in Romania-A demographic and qualitative approach of their employability. Rom. Stat. Rev. 2015, 63, 118-129.

2. Dostie, B.; Sahn, D.E. Labor Market Dynamics in Romania during a Period of Economic Liberalization; IZA Discussion Papers 2511; Institute of Labor Economics (IZA): Bonn, Germany, 2006; 36p.

3. Tudose, G.; Ţoţan, L.S.; Cristache, S.E. Models for the analysis of the labor market in Romania. Theor. Appl. Econ. 2013, 4, 113-122.

4. United Nations, Department of Economic and Social Affairs Disability. Convention on the Rights of Persons with Disabilities (CRPD). Available online: https://www.un.org/development/desa/disabilities/conventionon-the-rights-of-persons-with-disabilities.html (accessed on 22 August 2019).

5. Constitution of Romania, Amended and Completed by the Law No. 429/2003 on the Revision of the Constitution of Romania, Published in the Official Gazette of Romania, Part I, No. 758 of 29 October 2003, Republished by the Legislative Council on the Grounds of Article 152 of the Constitution, with the Updated Denominations and the Renumbered Texts (Article 152 Became, in the Republished form, Article 156), in the Official Gazette of Romania, Part I, No. 767 of 31 October 2003. Available online: http://www.cdep.ro/pls/dic/ site.page?id=371 (accessed on 20 August 2019).

6. Law no. 448/2006 amended and completed by the Government Emergency Ordinance no.60/2017 regarding the protection and promotion of the rights of persons with disabilities.

7. Hușman, A.I. Taxation of employees in Romania in 2018. Changes and its results on the country's economy. Oradea J. Bus. Econ. 2018, 3, 46-55. 
8. National Council for Combating Discrimination (NCCD). Available online: http://cncd.org.ro/ (accessed on 22 August 2019).

9. European Commission-European Web Site on Integration-Migrant Integration Information and Good Practices. Available online: https://ec.europa.eu/ (accessed on 22 August 2019).

10. Iova, A.R.; Crețu, D. Young persons insertion on the labor market. Case study in Romania and Bulgaria. Sci. Pap. Ser. Manag. Econ. Eng. Agric. Rural Dev. 2018, 18, 265-272.

11. Soare, E.; Chiurciu, I.A. Main tendencies in the labor market in the central region of Romania. Sci. Pap. Ser. Manag. Econ. Eng. Agric. Rural Dev. 2017, 17, 419-426.

12. Chivu, M.; Ion Pârgaru, I. The Romanian Higher Education and Labour Market-Requirements and Correlations. Bull. UASVM Hortic. 2011, 68, 41-48.

13. Zaman, C. The Failure to Restructure and Improve Efficiency on the Romanian Labor Market; CASE Network Studies and Analyses 0274, CASE-Center for Social and Economic Research, Studies \& Analyses No. 274; CASE-Center for Social and Economic Research: Warszawa, Poland, 2004; 14p. ISBN 83-7178-337-X.

14. Smatrakalev, G.S. Employment of People with Disabilities in Bulgaria-Problems and Perspectives (Integrated vs. Specialised Employment), Elsevier SSRN, Social Science Research Network Electronic Paper Collection. Available online: https://ssrn.com/abstract=265914 (accessed on 12 September 2019).

15. Stănescu, S.M. Innovatory Employment in Social Economy Busting Social Entrepreneurship Versus Regulating Social Insertion Enterprises. Rev. Soc. Interv. J. 2013, 43, 142-154.

16. Scharle, A.; Csillag, M. Disability and Labour Market Integration, European Commission; Publications Office of the European Union: Luxembourg, 2016; ISBN 978-92-79-63218-1. [CrossRef]

17. Magrin, M.E.; Marini, E.; Nicolotti, M. Employability of Disabled Graduates: Resources for a Sustainable Employment. Sustainability 2019, 11, 1542. [CrossRef]

18. Alexiu, T.M.; Baciu, E.L.; Sandvin, J.; Fyling, I.; Breimo Paulsen, J.; Bîrneanu, A.; Lazăr, T.A.; Dincă, M.; Zamfirescu, I. Investigating the Institutional Relations and Structural Mechanisms Underpinning the Hindrances and Barriers to Employment Experienced by Disabled Individuals in Romania. 2015. Available online: http://www.e-qual-see.ro/wp-content/uploads/2015/08/Hindrances-and-barriers-toemployment.-Experiences-of-the-disabled-persons-in-Romania.pdf (accessed on 10 June 2019).

19. Reinhardt, J.D.; Post, M.W.; Fekete, C.; Trezzini, B.; Brinkhof, M.W.; SwiSCI Study Group. Labor Market Integration of People with Disabilities: Results from the Swiss Spinal Cord Injury Cohort Study. PLoS ONE 2016, 11, e0166955. [CrossRef]

20. Mihai, B.; Constantin, A.; Andone, I.; Anghelescu, L.A.; Magdoiu, A.M.; Onose, G. Employment of People with Disabilities in Romania. Int. Arch. Med. 2016. [CrossRef]

21. Balazs-Foldi, E. Equal Opportunities in The Italian Labour Market. Ann. Fac. Econ. 2015, 1, 142-156.

22. Levitas, R. The concept of social exclusion and the new Durkheimian hegemony. Crit. Soc. Policy 1996, 16, 5-20. [CrossRef]

23. Warren, J. Disabled people, the state and employment: Historical lessons and welfare policy. In Working Futures: Disabled People, Policy and Social Inclusion; Roulstone, A., Barnes, C., Eds.; The Policy Press: Bristol, UK, 2005; pp. 301-313.

24. Duffy, K. Social Exclusion and Human Dignity in Europe; Council of Europe: St. Petersburg, France, 1995.

25. Garrido-Cumbrera, M.; Chacón-García, J. Assessing the Impact of the 2008 Financial Crisis on the Labor Force, Employment, and Wages of Persons with Disabilities in Spain. J. Disabil. Policy Stud. 2018, 29, 178-188. [CrossRef]

26. Kuznetsova, Y.; Yalcin, B.; Priestley, M. Labour market integration and equality for disabled people: A comparative analysis of Nordic and Baltic countries. Soc. Policy Adm. 2017, 51, 577-597. [CrossRef]

27. United Nations Educational, Scientific and Cultural Organization (UNESCO). Available online: http: //www.unesco.org/new/en/social-and-human-sciences/ (accessed on 10 June 2019).

28. Vornholt, K.; Villotti, P.; Muschalla, B.; Bauer, J.; Colella, A.; Zijlstra, F.; Van Ruitenbeek, G.; Uitdewilligen, S.; Corbière, M. Disability and employment-Overview and highlights. Eur. J. Work Organ. Psychol. 2018, 27, 40-55. [CrossRef]

29. Vilà, M.; Pallisera, M.; Fullana, J. Work integration of people with disabilities in the regular labour market: What can we do to improve these processes? J. Intellect. Dev. Disabil. 2007, 32, 10-18. [CrossRef] 
30. Wolniak, R.; Skotnicka-Zasadzien, B. Developing a Model of Factors Influencing the Quality of Service for Disabled Customers in the Condition s of Sustainable Development, Illustrated by an Example of the Silesian Voivodeship Public Administration. Sustainability 2018, 10, 2171. [CrossRef]

31. Thomas, C. Female Forms: Experiencing and Understanding Disability; Open University Press: Buckingham, $\mathrm{UK}, 1999 ; 175 \mathrm{p}$.

32. Mateescu, L.M.; Neagu, A.M. Opportunities of labour market integration for young professionals. Procedia Econ. Financ. 2014, 8, 444-452. [CrossRef]

33. Bălan, M.; Uzlău, C.; Ene, C.M. Transition from Educational System to Labour Market in Romania. Procedia Soc. Behav. Sci. 2013, 92, 314-322. [CrossRef]

34. Diaconu (Maxim), L. Education and labour market outcomes in Romania. East. J. Eur. Stud. 2014, 5, 99-112.

35. Bliksvær, T. Disability, Labour Market Participation and the Effect of Educational Level: Compared to What? Scand. J. Disabil. Res. 2018, 20, 6-17. [CrossRef]

36. Baciu, E.L.; Lazar, T.A. Between Equality and Discrimination: Disabled Persons in Romania. Transylv. Rev. Adm. Sci. 2017, 51, 5-19. [CrossRef]

37. Cindrea, I. The Crisis on the Labor Market in Romania. Theor. Appl. Econ. 2007, 4, 25-28.

38. Backenroth, G.A. People with disabilities and the changing labor market: Some challenges for counseling practice and research on workplace counseling. Int. J. Adv. Couns. 2001, 23, 21-30. [CrossRef]

39. Dănăcică, D.E.; Cîrnu, D. Unemployment Duration and Exit States of Disabled People in Romania. Rom. J. Econ. Forecast. 2014, 17, 35-53.

40. Agovino, M.; Rapposelli, A. Inclusion of disabled people in the Italian labour market: An efficiency analysis of law 68/1999 at regional level. Qual. Quant. 2013, 47, 1577-1588. [CrossRef]

41. Boajă, D.M. Influence of undeclared work on the Romanian labor market. Int. J. Acad. Res. Econ. Manag. Sci. 2012, 1, 217.

42. Davey, S.; Gordon, S. Definitions of social inclusion and social exclusion: The invisibility of mental illness and the social conditions of participation. Int. J. Cult. Ment. Health 2017, 10, 229-237. [CrossRef]

43. Nenu, C.C. Labor Code Amendments-Between Necessity and the Reality of the Labor Market in Romania and in the European Union. J. Leg. Stud. 2012, 1,77-86.

44. World Health Organization: WHO. International Classification of Functioning, Disability and Health (ICF). Available online: https://www.who.int/classifications/icf/en/ (accessed on 15 June 2019).

(C) 2019 by the authors. Licensee MDPI, Basel, Switzerland. This article is an open access article distributed under the terms and conditions of the Creative Commons Attribution (CC BY) license (http://creativecommons.org/licenses/by/4.0/). 